\title{
Anomalous Late Jurassic motion of the Pacific Plate with implications for true polar wander
}

\author{
Roger R. Fu ${ }^{\mathrm{a}, \mathrm{b}, *}$, Dennis V. Kent ${ }^{\mathrm{a}, \mathrm{c}}$ \\ a Lamont-Doherty Earth Observatory, Columbia University, Paleomagnetics Laboratory, 61 Route 9W, Palisades, NY 10964, USA \\ ${ }^{\mathrm{b}}$ Department of Earth and Planetary Sciences, Harvard University, 20 Oxford St., Cambridge, MA 02138, USA \\ ${ }^{c}$ Department of Earth and Planetary Science, Rutgers University, 610 Taylor Rd, Piscataway, NY 08854, USA
}

\section{A R T I C L E I N F O}

\section{Article history:}

Received 25 May 2017

Received in revised form 19 February 2018

Accepted 25 February 2018

Available online $\mathrm{xxxx}$

Editor: B. Buffett

\section{Keywords:}

paleomagnetism

true polar wander

tectonics

Ocean Drilling Program

geodynamics

Jurassic

\begin{abstract}
A B S T R A C T
True polar wander, or TPW, is the rotation of the entire mantle-crust system about an equatorial axis that results in a coherent velocity contribution for all lithospheric plates. One of the most recent candidate TPW events consists of a $\sim 30^{\circ}$ rotation during Late Jurassic time (160-145 Ma). However, existing paleomagnetic documentation of this event derives exclusively from continents, which compose less than $50 \%$ of the Earth's surface area and may not reflect motion of the entire mantle-crust system. Additional paleopositional information from the Pacific Basin would significantly enhance coverage of the Earth's surface and allow more rigorous testing for the occurrence of TPW. We perform paleomagnetic analyses on core samples from Ocean Drilling Program (ODP) Site 801B, which were taken from the oldest available Pacific crust, to determine its paleolatitude during the Late Jurassic and Early Cretaceous (167-133 Ma). We find that the Pacific Plate underwent a steady southward drift of $0.49^{\circ}-0.74^{\circ} \mathrm{My}^{-1}$ except for an interval between Kimmeridgian and Tithonian time (157-147 Ma), during which it underwent northward motion at $1.45^{\circ} \pm 0.76^{\circ} \mathrm{My}^{-1}(1 \sigma)$. This trajectory indicates that the plates of the Pacific Basin participated in the same large-amplitude $\left(\sim 30^{\circ}\right)$ rotation as continental lithosphere in the 160-145 Ma interval. Such coherent motion of a large majority of the Earth's surface strongly supports the occurrence of TPW, suggesting that a combination of subducting slabs and rising mantle plumes was sufficient to significantly perturb the Earth's inertia tensor in the Late Jurassic.
\end{abstract}

(c) 2018 Elsevier B.V. All rights reserved.

\section{Introduction}

Paleomagnetic experiments can quantify the progressive change in the latitude of lithospheric blocks through time. Such latitudinal drift can result from the motion of lithospheric plates over the mantle (hereafter referred to as "tectonic motion") or true polar wander. The latter mechanism, abbreviated TPW, is defined as the rotation of the entire mantle-crust system around the outer core due to changes in the Earth's inertia tensor, which may arise from the redistribution of mass anomalies within the mantle or on the surface (Creveling et al., 2012; Gold, 1955). TPW is an ongoing process on the modern Earth, where an $\sim 1^{\circ} \mathrm{My}^{-1}$ rotation of the geographic north pole towards the Hudson Bay is primarily driven by Pleistocene deglaciation with a significant component likely due to mantle flow (Wu and Peltier, 1984; Gordon, 1995; Steinberger and O'Connell, 2002). Due to the relationship between TPW and motions in the Earth's deep interior, characterization of

\footnotetext{
* Corresponding author.

E-mail address: rogerfu@fas.harvard.edu (R.R. Fu).
}

TPW in the geological past may offer unique insights into ancient mantle dynamics (Greff-Lefftz and Besse, 2014).

The differential motion of lithospheric plates over the deep mantle complicates the characterization of TPW in the geological past. Because TPW is defined as coherent rotation of the entire mantle-crust system, the motion of the deep mantle should also be known to demonstrate conclusively the occurrence of TPW. Since $\sim 130 \mathrm{Ma}$, the Indo-Atlantic hotspot reference frame has been used to infer the orientation of the deep mantle (Müller et al., 1993), potentially permitting a quantitative description of TPW during this time (e.g., Gordon and Jurdy, 1986; Torsvik et al., 2008). Some investigations into the post-130 Ma past have interpreted motion of Pacific hotspots with respect to the rotation axis as TPW at 84-85 Ma (Gordon, 1983; Sager and Koppers, 2000). However, the occurrence of anomalous motion at the same time in the continental domain remains unclear (Cottrell and Tarduno, 2000).

The oldest hotspot track likely to have a deep mantle origin is Tristan da Cunha, which is traceable to 130 Ma (Courtillot et al., 2003). Therefore, studies of global lithospheric motion before that time have relied on indirect arguments to establish the occurrence of TPW. Most commonly, coherent motion of multiple 

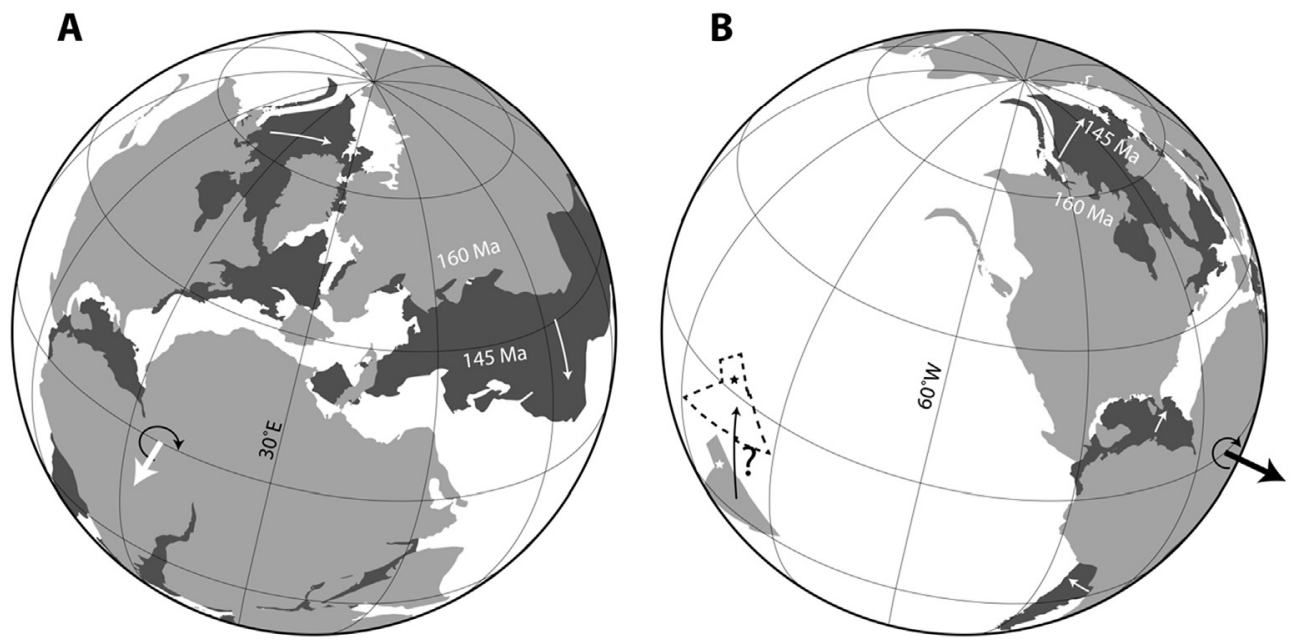

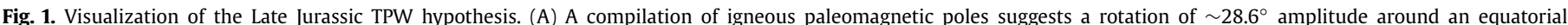

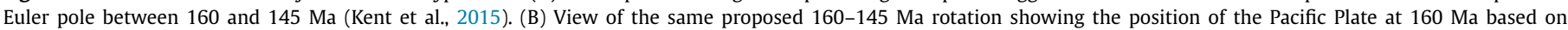

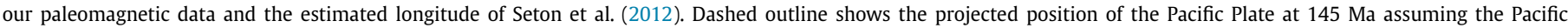

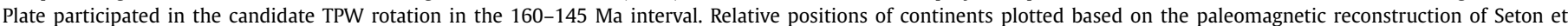
al. (2012).

lithospheric plates (i.e., the combined Euler rotation vector for a set of area-weighted plates) has been interpreted to provide evidence for TPW (McKenzie, 1972; McElhinny, 1973; Jurdy and Van der Voo, 1974). Such a global compilation of plate velocities permits the quantification of net lithosphere rotation, which, in the strict sense, describes only the motion of the crust and lithospheric mantle.

Geodynamical arguments can relate the net rotation of the lithosphere to that of the deep mantle, thereby permitting inferences of TPW. In an idealized crust-mantle system, the condition that net torque on all lithospheric plates sums to zero implies that no net rotation of the lithosphere can occur with respect to the deep mantle (Solomon and Sleep, 1974). In such a scenario, a net rotation of the lithosphere would correspond directly to rotation of the entire crust-mantle system and thereby fully quantify TPW. However, due to laterally heterogeneous rheologies and unbalanced forces at plate margins, the zero net torque condition is not equivalent to zero net lithospheric rotation, implying that knowledge of lithospheric motion, even of the entire globe, does not precisely constrain the motion of the deep mantle frame (Solomon and Sleep, 1974).

Even so, coherent lithospheric motion may constitute an imperfect but acceptable proxy for motion of the deep mantle frame because net rotation of the lithosphere is empirically small, estimated to be between $0.1^{\circ}$ and $0.2^{\circ} \mathrm{My}^{-1}$ over the last $60 \mathrm{My}$ (Jurdy and Van der Voo, 1974; Gordon and Jurdy, 1986). Furthermore, this rate of net rotation agrees with expectations from the power of toroidal motion at higher spherical harmonic degrees, supporting the idea that the low observed rate is a natural consequence of mantle dynamics (O'Connell and Hager, 1990). Finally, numerical simulations of mantle convection show that net rotations faster than $\sim 0.2^{\circ} \mathrm{My}^{-1}$ are difficult to produce without extremely deep continental keels (Zhong, 2001). In summary, if the net motion of the entire lithosphere or a large majority thereof is known, the motion of the entire crust-mantle frame, and hence the occurrence of TPW, can be quantified with uncertainty of order $0.2^{\circ} \mathrm{My}^{-1}$.

Based on these arguments, most paleomagnetic studies of the $>130$ Ma past use observations of coherent plate motion to infer TPW. For example, Torsvik et al. (2012) proposed four episodes of possible TPW between 250 and 100 Ma by identifying apparently coherent rotations of continents around a specific equatorial axis through the large low shear velocity provinces (LLSVPs) of the lower mantle. Among these, two episodes can be combined into a single clockwise rotation of $30.5^{\circ}$ around an equatorial Euler pole at $11^{\circ} \mathrm{E}$ longitude (South African coordinates) between 200 and $140 \mathrm{Ma}$. An alternative compilation by Kent and Irving (2010) using a much more stringent quality filter for individual poles shows a rotation with similar amplitude $\left(28.6^{\circ}\right)$ and similar equatorial Euler pole ( $\sim 10^{\circ} \mathrm{W}$ in NW African coordinates), but with much higher rate of $\sim 2^{\circ} \mathrm{My}^{-1}$ focused between 160 and 145 Ma. Subsequent studies have shown that this 160-145 Ma rotation is consistent with stringently selected igneous paleomagnetic poles from North America, South America, Adria, South Africa, and Australia (Muttoni et al., 2013), leading Kent et al. (2015) to hypothesize that the $28.6^{\circ}$ motion between approximately 160 and $145 \mathrm{Ma}$ constitutes an episode of TPW (Fig. 1). If confirmed as such, this event would represent the most recent TPW of large $\left(\geq 25^{\circ}\right)$ amplitude in Earth history.

However, as with all other periods of possible TPW before $130 \mathrm{Ma}$, the motion of large fractions of the Earth's lithosphere remains poorly constrained in the Late Jurassic. The positions and velocities of all continental plates (except the United China Block; Van der Voo et al., 2015) and the nascent Atlantic Basin during the Late Jurassic may be quantified using a combination of paleomagnetic poles and seafloor magnetic lineations. However, the motion of the Pacific Basin, comprising the Pacific, Farallon, Izanagi, Phoenix, and possibly additional plates, remains poorly known in the same time interval (Larson et al., 1992). Because the lithosphere outside the Pacific Basin composed only approximately $50 \%$ of the Earth's surface area, coherent motion of the continental plates may not constitute a net rotation of the lithosphere, thereby weakening the relationship between their motion and that of the deep mantle. As such, paleomagnetic data from the continents alone cannot rigorously test the occurrence of TPW.

The recovery of paleoposition information for plates in the Pacific Basin during the Late Jurassic would provide key additional information regarding the occurrence of TPW. Because the relative motions of the Pacific, Farallon, Izanagi, and Phoenix plates are known from seafloor magnetic lineations, paleomagnetic determination of Pacific Plate motion would constrain the position of a significant additional fraction of the lithosphere. As such, if paleomagnetic data from the Pacific Plate suggest that the Pacific Basin plates participated in the same rotation as the continental plates during the $160-145 \mathrm{Ma}$ interval, the combined motion would involve a large majority of the lithosphere and is therefore 
quantitatively coupled to motion in the deep mantle frame as described above. We note that such information cannot be recovered from earlier intervals of proposed TPW due to the lack of surviving oceanic crust, thereby precluding the determination of motion for a majority of the Earth's lithosphere. The candidate TPW episode in the Late Jurassic therefore represents the only known opportunity to determine rigorously the occurrence of TPW in the absence of a hotspot reference frame.

Based on the compiled paleomagnetic data from the continents, the TPW hypothesis between 160 and 145 Ma predicts a rapid northward shift in the velocity of the Pacific Plate. The exact rate of expected northward motion depends on the paleolongitude of the Pacific Plate, which is not precisely known. Adopting a paleolongitude of $112^{\circ} \mathrm{W}$, which assumes no longitudinal motion prior to 140 Ma due to a lack of constraints (Seton et al., 2012), the hypothesized TPW rotation between 160 and 145 Ma would contribute a northward motion of $1.87^{\circ} \mathrm{My}^{-1}$ to the core of the Pacific Plate relative to the Earth's rotation axis. Extending the $0.63^{\circ} \mathrm{My}^{-1}$ eastward drift of the Pacific Plate in the 140-120 Ma interval (Seton et al., 2012) back to $160 \mathrm{Ma}$ results in a paleolongitude of $100^{\circ} \mathrm{W}$, implying that the velocity of the Pacific Plate would have a northward component of $1.91^{\circ} \mathrm{My}^{-1}$ between 160 and $145 \mathrm{Ma}$. We therefore find that uncertainty in paleolongitude results in negligible change in the drift rate predicted by TPW.

In this work, we test the above TPW-based predictions for the north-south velocity of the Pacific Plate by performing paleomagnetic experiments on sedimentary and igneous samples from Ocean Drilling Program (ODP) Site 801B. This core, along with the deeper basaltic Site 801C, were taken in 1990 on ODP Leg 129 and represent the oldest material recovered from the Pacific Plate. Although both cores have been studied paleomagnetically (Steiner and Wallick, 1992; Tauxe et al., 2013; Wallick and Steiner, 1992), previous sampling focused mainly on paleointensities and magnetization directions of underlying Bathonian basalts or on younger sediments of less than middle Tithonian age ( $<155 \mathrm{Ma})$.

To extend these results to earlier time intervals, we specifically pursue exhaustive sampling of the lowermost recovered sedimentary and igneous units in the Site 801B core (167-133 Ma). By combining our paleolatitudes with radiolarian-based biostratigraphy, we show that the Pacific Plate underwent steady southward motion during the sampled interval except for a period of anomalous northward drift between approximately 157 and 147 Ma. Participation in a TPW rotation during this time interval is the most likely explanation for the observed net northward velocity under a range of assumptions about the tectonic component of motion of the Pacific Plate. We therefore find that the Pacific Plate participated in the same large amplitude rotation around an equatorial Euler pole as the continental lithosphere between 160 and $145 \mathrm{Ma}$, supporting the occurrence of TPW in this time interval.

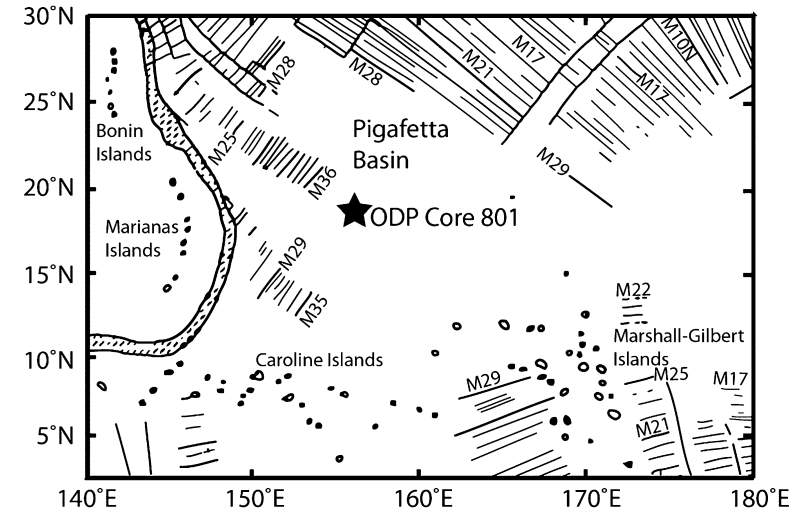

Fig. 2. Map of the Pigafetta Basin area of the western Pacific Ocean showing the location of ODP Core 801B from which our samples were taken. Map adapted from Larson et al. (1992).

\section{Samples and methods}

All paleomagnetic samples used in this study were collected from ODP Site $801 \mathrm{~B}\left(18^{\circ} 38.52^{\prime} \mathrm{N} ; 156^{\circ} 21.582 \mathrm{E}\right)$, which was taken from the Pigafetta Basin of the western Pacific Ocean (Fig. 2; Lancelot et al., 1990). We extracted 67 sedimentary samples between 309.22 and 476.98 meters below sea-floor (mbsf). Lithologies of sampled sedimentary rocks consist primarily of cherts interbedded with red radiolarites and claystones (Fig. 3), while the lowermost three chert samples were found interbedded with basaltic flows. In addition, we took 30 igneous samples from between 461.88 and 503.83 mbsf. Both sedimentary and igneous samples were curated at the Gulf Coast Repository at Texas A\&M University, where they have been kept at $4{ }^{\circ} \mathrm{C}$ in the Earth's magnetic field since their recovery in 1990 . We oriented all samples in the vertical direction based on their position in the original core and pre-existing orientation marks. All samples were taken from the working split of the ODP cores and represent the last available oriented samples for most depths below $\sim 430 \mathrm{mbsf}(\sim 154 \mathrm{Ma}$; see below).

Sedimentary samples within our stratigraphic interval have been dated to between the middle Bathonian and late Valanginian based on radiolarian fossils by Matsuoka (1992), who divided the section into six biostratigraphic zones. Revised biozone designations by Matsuoka (1995) generally reaffirmed those of the earlier study except for a reassignment of the 29R-32R core segments (zone JR7) from the Tithonian to the Kimmeridgian (Table 1). Analysis of calcareous nannofossils revealed a Tithonian nannoflora assemblage in the 25R-26R core interval, which supports the radiolarian chronologies (Erba and Covington, 1992). Subsequent $\mathrm{Ar}-\mathrm{Ar}$ dating of the underlying basalts resulted in an age of $167.7 \pm 1.4$ Ma (Koppers et al., 2003), which is fully consistent with the biostratigraphic constraints above and with a study of interbedded radiolarians at Site $801 \mathrm{C}$ that yielded a middle Bathonian age

Table 1

Comparison of radiolarian-based biostratigraphy for ODP core 801B based on Matsuoka (1992, 1995).

\begin{tabular}{|c|c|c|c|c|c|c|}
\hline \multirow[t]{2}{*}{ Core range } & \multicolumn{3}{|l|}{ Matsuoka, 1992} & \multicolumn{3}{|l|}{ Matsuoka, 1995} \\
\hline & Stage assignment & $\begin{array}{l}\text { Age range } \\
\text { (Ma) }\end{array}$ & $\begin{array}{l}\text { Mean age } \\
\text { (Ma) }\end{array}$ & Stage assignment & $\begin{array}{l}\text { Age range } \\
\text { (Ma) }\end{array}$ & $\begin{array}{l}\text { Mean age } \\
\text { (Ma) }\end{array}$ \\
\hline $13 R-14 R$ & Val. & $139.4-133.9$ & 136.6 & Upper Val.-Lower Haut. & $137.1-132.9$ & 135.0 \\
\hline $15 R-20 R$ & Upper Tith.-Lower Val. & $146.7-137.2$ & 141.9 & Upper Tith.-Lower Val. & $146.7-137.2$ & 141.9 \\
\hline $21 R-28 R$ & Kimm.-Upper Tith. & $157.3-146.7$ & 152.0 & Lower Tith.-Middle Tith. & $152.1-146.7$ & 149.4 \\
\hline $29 R-32 R$ & Oxf. & $163.5-157.3$ & 160.4 & Kimm. & $157.3-152.1$ & 154.7 \\
\hline $33 R-34 R$ & Upper Call. & $164.8-163.5$ & 164.2 & Upper Call.-Lower Oxf. & $164.8-160.9$ & 162.9 \\
\hline $34 R-39 R$ & Upper Bath.-Lower Call. & $167.1-164.8$ & 165.9 & Upper Bath.-Lower Call. & $167.1-164.8$ & 165.9 \\
\hline
\end{tabular}

Notes: Stage abbreviations are: Val. - Valanginian, Tith. - Tithonian, Kimm. - Kimmeridgian, Oxf. - Oxfordian, Call. - Callovian, Bath. - Bathonian. Numerical age ranges are based on the Geomagnetic Polarity Timescale (GPTS) of Ogg (2012). 


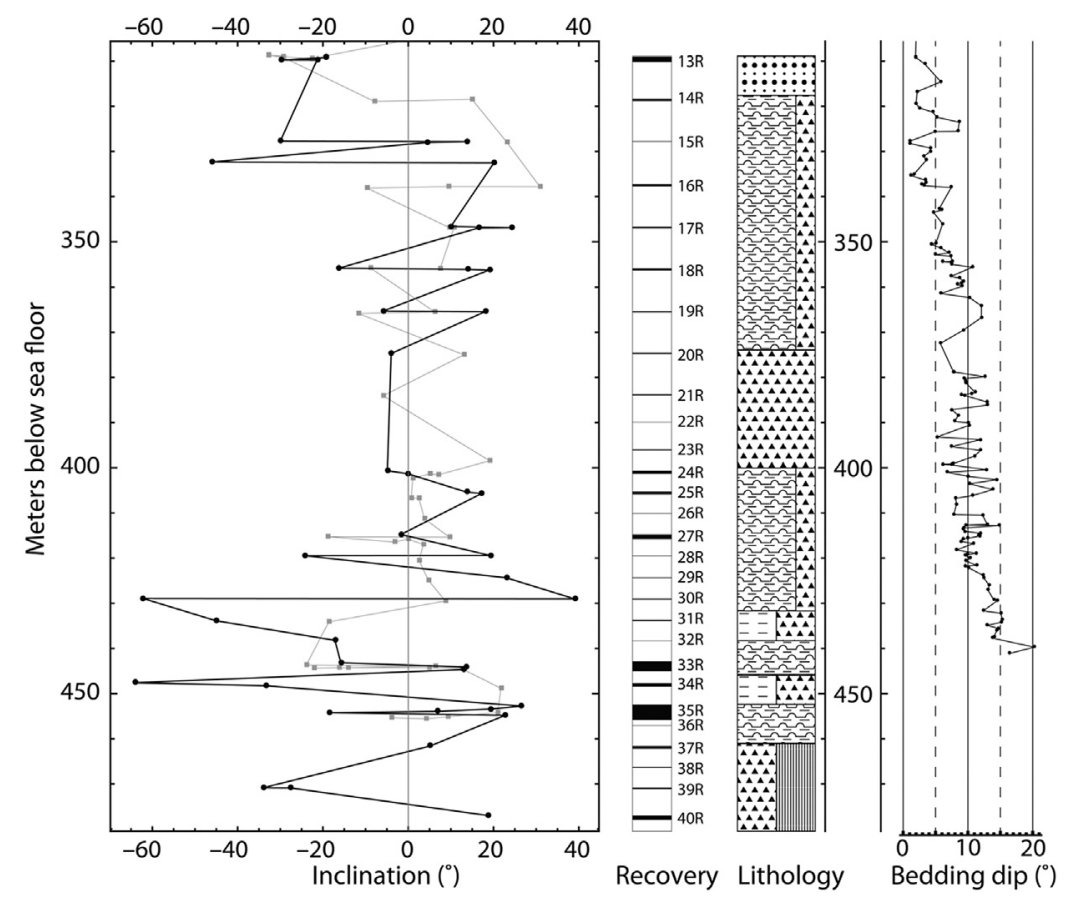

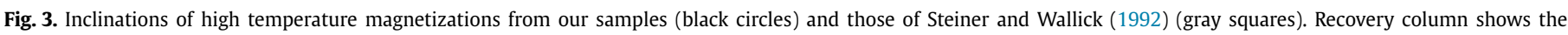

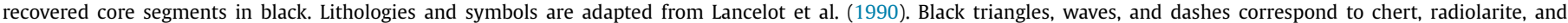

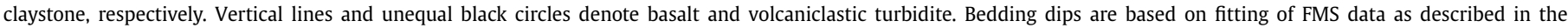
text.

(Bartolini and Larson, 2001). In this study, we assign ages to our sedimentary samples based on the chronology of Matsuoka (1995) while adopting a cooling age of $167.7 \pm 1.4$ Ma for our igneous samples. We also compute and discuss drift velocities using the chronology of Matsuoka (1992), finding that the choice between these two chronologies does not change our conclusions regarding Pacific Plate motion.

We performed stepwise thermal demagnetization on all samples using steps of $40-45^{\circ} \mathrm{C}$ for temperatures between 75 and $480^{\circ} \mathrm{C}$ and finer steps of $15-30^{\circ} \mathrm{C}$ between 480 and $690^{\circ} \mathrm{C}$. All samples were measured on the $2 \mathrm{G}$ Enterprises model 760 Superconducting Rock Magnetometer, which has an effective noise floor of $10^{-11} \mathrm{Am}^{2}$ and is housed in the shielded room at the LamontDoherty Earth Observatory (LDEO). Please see Data in Brief for all raw data. We then identified and fitted components of magnetization using principal components analysis (Kirschvink, 1980).

To estimate the bedding attitude throughout the depth range of our samples, we used the GeoFrame software at the LDEO Borehole Laboratory to fit Formation MicroScanner (FMS) data at 135 depth intervals between 295.97 and 440.05 mbsf (Table S1). The clarity of the FMS data was insufficient to provide reliable bedding measurements at greater depths. We find that beds in this depth range generally dip between 5 and $15^{\circ}$ to the southwest, with the deepest beds exhibiting the steepest dip (Fig. 3). Except for the interpretation of a large $50^{\circ}$ dip at $451.6-435.5 \mathrm{mbsf}$, our FMS-derived bedding attitudes are consistent with the initial study by Molinie and Ogg (1992).

\section{Results}

\subsection{Sedimentary samples}

Nearly all sedimentary samples (64 out of 67) exhibited at least two stable components of magnetization during thermal demagnetization (Fig. 4; Table S2). Secondary components of magnetization in these samples may be due to viscous remanent magnetization
(VRM) or remagnetization during the drilling process. A VRM acquired during the Brunhes normal chron is expected to be blocked up to approximately 150 and $200^{\circ} \mathrm{C}$ in the case of single domain magnetite and hematite carriers, respectively (Dunlop and Ozdemir, 1997). As such, any component of magnetization representing a characteristic remanent magnetization (ChRM) from the Late Jurassic and Early Cretaceous is expected to have minimum unblocking temperatures in excesses of $150-200^{\circ} \mathrm{C}$. Adopting a conservative approach, we interpret as a candidate ChRM only high temperature $(\mathrm{H})$ components of magnetization that are blocked between $\geq 200^{\circ} \mathrm{C}$ and $\geq 540^{\circ} \mathrm{C}$ and have a maximum angular deviation (MAD) of $\leq 15.0^{\circ}$. Following this criterion, 43 out of 67 sedimentary samples retain a probable ChRM (Table S2).

Because some low temperature components of magnetization are likely to be VRMs acquired in the present-day field, we use these components to estimate the direction of true north in our samples. In case of samples with multiple magnetization directions unblocking $\leq 280^{\circ} \mathrm{C}$, we refer to the lower and higher temperature components as L0 and L, respectively. The L0 component, where present, is typically completely removed by $75^{\circ} \mathrm{C}$. We interpret this component as a VRM acquired during sample handling or curation and exclude it from further analysis. For the higherunblocking L magnetizations, we first hypothesize that all examples of this magnetization with positive inclination are VRMs in origin (mean local dipole field at drilling site has $34.0^{\circ}$ inclination). We find that 26 samples carry such a magnetization (Fig. 5A), among which 21 samples also carry an $\mathrm{H}$ magnetization interpreted to be a ChRM. We then rotate both the $\mathrm{L}$ and $\mathrm{H}$ components of magnetization in each of the 21 samples such that the L component has a declination of $0^{\circ}$, which is expected for a recent VRM.

After rotation, the $\mathrm{H}$ directions fall into two nearly antipodal clusters (Fig. 5B). We then apply tilt correction to the rotated directions based on FMS data (see below). Because the scatter of both $\mathrm{L}$ and $\mathrm{H}$ components contributes to the declination scatter but not the inclination scatter of the rotated dataset, the distribution of rotated $\mathrm{H}$ directions is non-Fisherian and therefore cannot be used to perform a rigorous reversal test using the formalism 
A

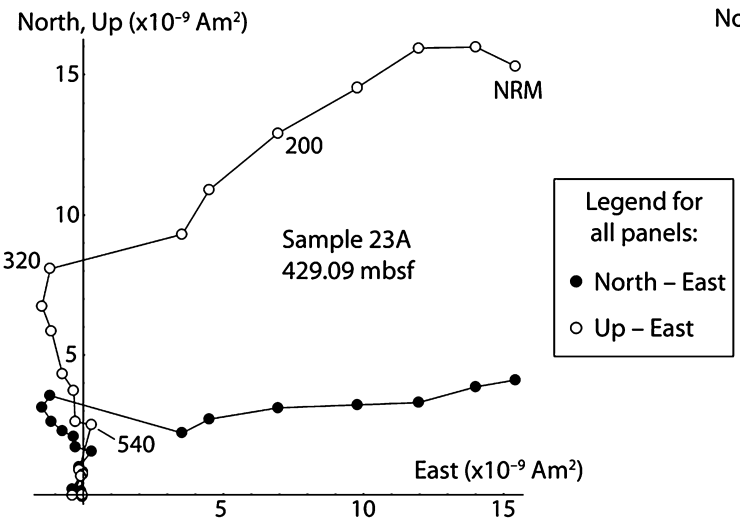

C

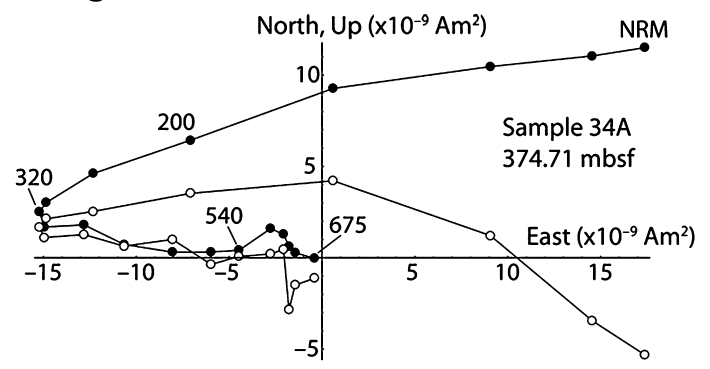

D

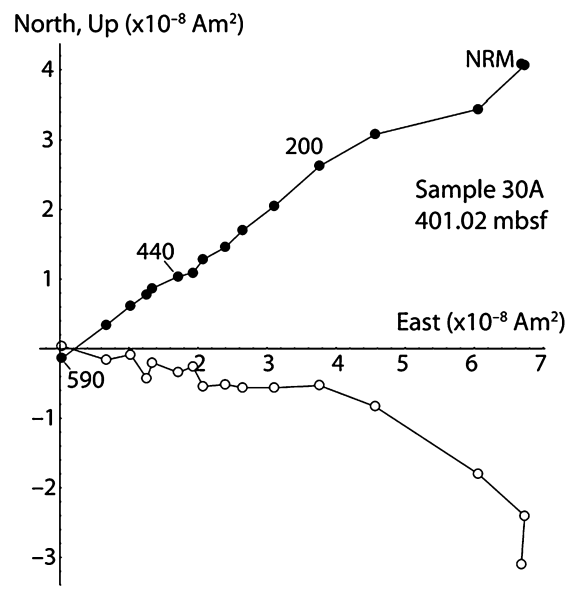

B

North, Up (x10-9 $\left.\mathrm{Am}^{2}\right)$

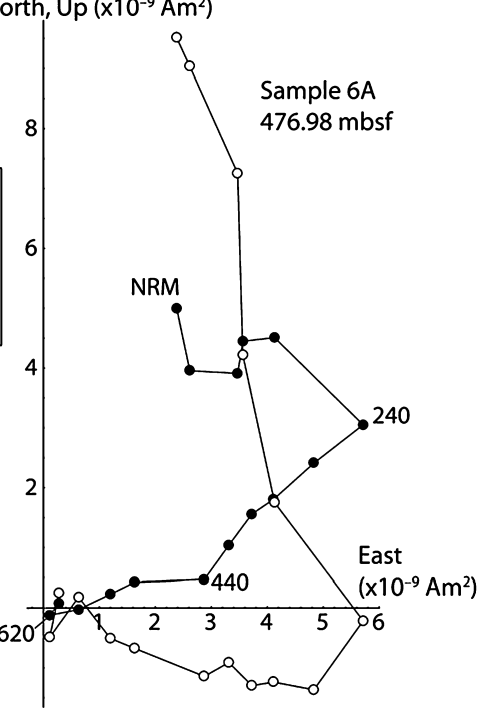

E

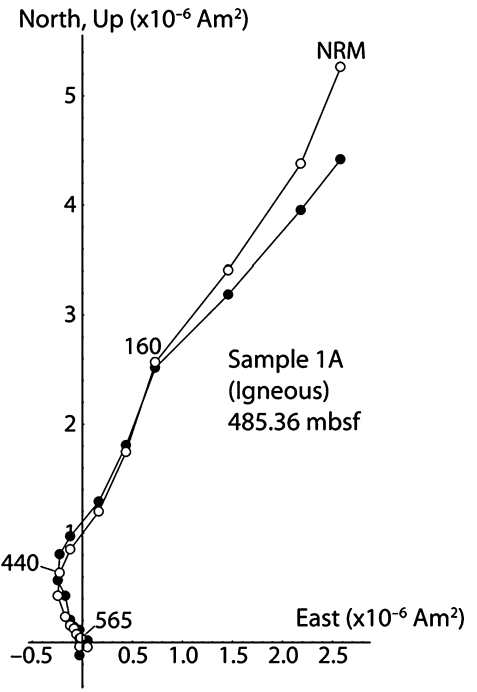

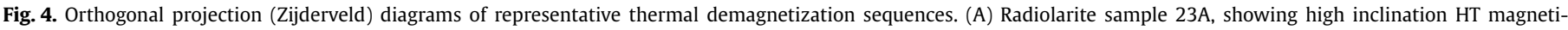

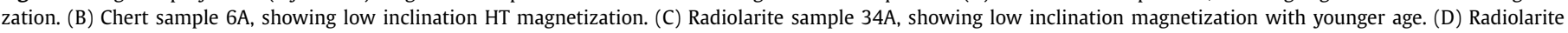

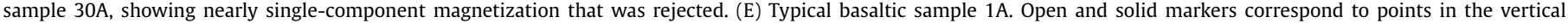
and horizontal planes, respectively.

of McFadden and McElhinny (1990). We note, however, that if such a test is applied, the $\gamma_{c}$ parameter as defined by McFadden and McElhinny (1990) is found to be $24.5^{\circ}$, which by convention indicates an indeterminate reversal test. Such a large confidence interval is consistent with data that have been rotated based on VRM components subject to significant scatter. The angular separation between group means is $15.9^{\circ}$ after one set is reflected through the origin, which is significantly less than $\gamma_{c}$ and shows that the $\mathrm{H}$ directions are consistent with the presence of normal and reversed primary magnetizations. The inclinations of the rotated $\mathrm{H}$ directions imply that the magnetizations were acquired in the southern hemisphere at all stratigraphic levels, confirming the interpretation of Steiner and Wallick (1992).

The declinations of the rotated $\mathrm{H}$ directions may be used to infer the amount of vertical axis rotation experienced by the Pacific plate since the Late Jurassic. After transforming all re- versed $\mathrm{H}$ directions to their normal polarity equivalents, we compute a mean declination of $1.9^{\circ} \pm 5.9^{\circ}(1 \sigma)$. Excluding the outlier $\mathrm{H}$ directions from samples $11 \mathrm{~A}$ and $25 \mathrm{~B}$ results in a mean declination of $356.7^{\circ} \pm 4.8^{\circ}$. Performing the same analysis without tilt-correction results in mean declinations of $2.8^{\circ} \pm 5.9^{\circ}$ and $357.9^{\circ} \pm 5.0^{\circ}$, which are indistinguishable from the tilt-corrected values. Furthermore, we find no identifiable trend in sample declination as a function of stratigraphic height, thereby providing no evidence of vertical axis rotation during the interval of deposition (Fig. 5B). We therefore conclude that no resolvable vertical axis rotation has occurred to the Pacific plate. Future recovery of azimuthally oriented core samples would be able to test this inference as well as generate an apparent polar wander (APW) path for the Pacific Plate, thereby testing of the Late Jurassic TPW hypothesis without an assumption of Pacific Plate paleolongitude. 
A

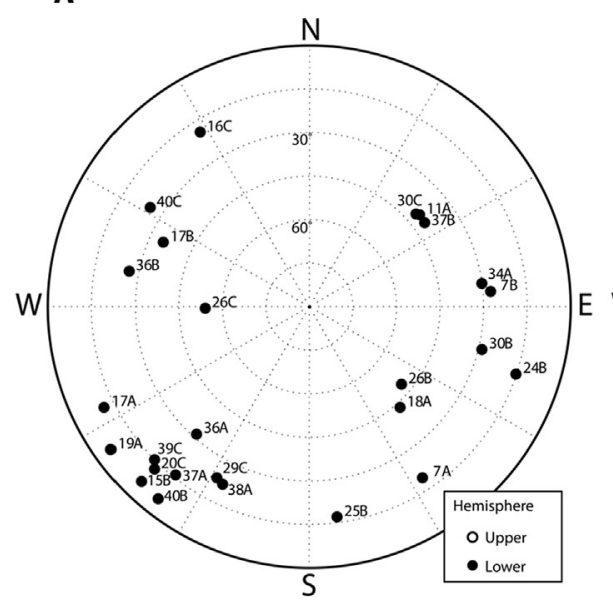

B

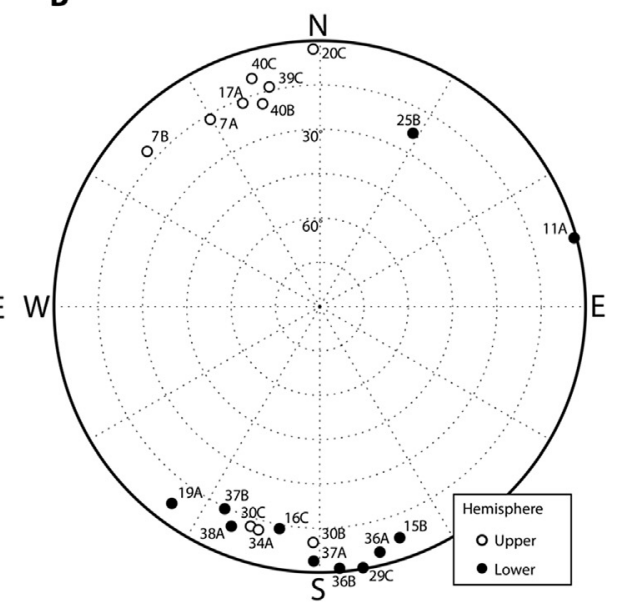

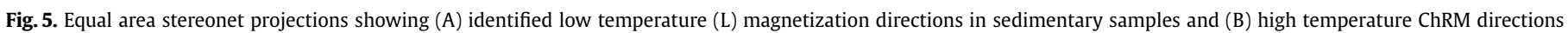

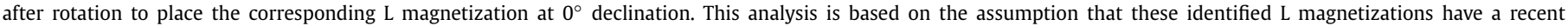
VRM origin. Note the clustering of $\mathrm{H}$ directions in north-south antipodal groups. See text for quality criteria used to identify L and $\mathrm{H}$ magnetization.
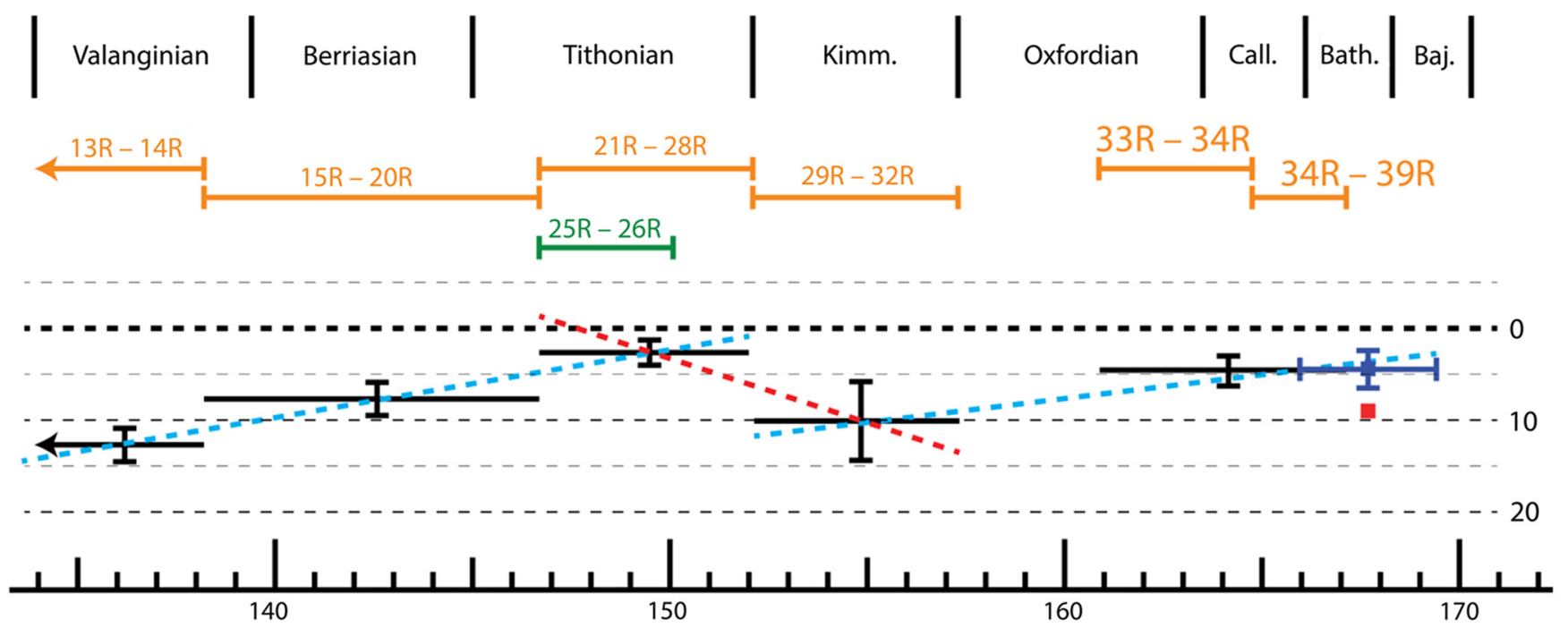

Age (Ma)
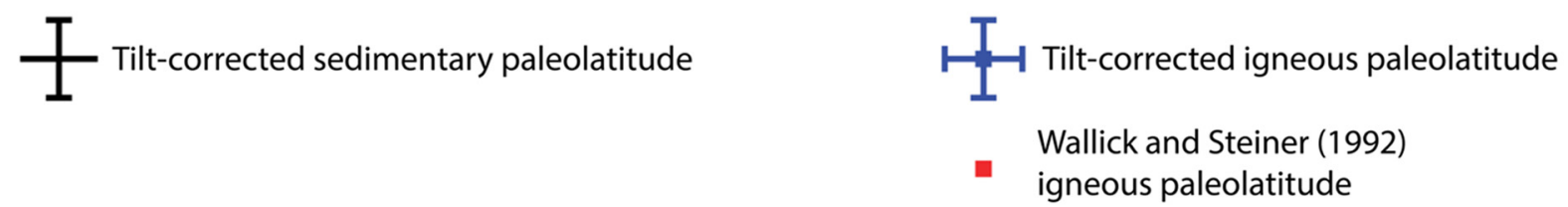

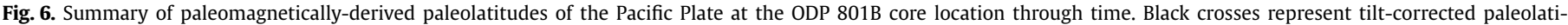

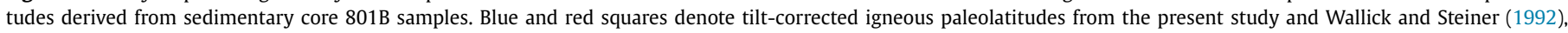

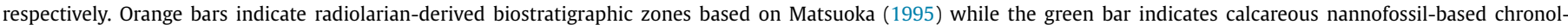

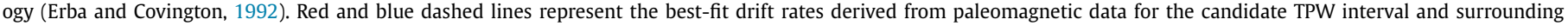
times, respectively. Ages of Jurassic and Cretaceous stages are based on the Geomagnetic Polarity Timescale (GPTS) 2012 (Ogg, 2012 ).

Adopting a paleodeclination of $0^{\circ}$ based on the above analysis, we use azimuthally oriented FMS resistivity measurements to compute tilt-corrected directions for the ChRM (Fig. 3; Table S1). For each of the four youngest biostratigraphic zones, we compute a mean bedding attitude in the corresponding depth range to apply the correction. Because no reliable FMS measurements are available for the lowest biozones (JR5-JR6), we apply the tilt correction computed from the immediately overlying sediments of Kimmeridgian age. We then compute the paleolatitude of the Pacific Plate based on the tilt-corrected ChRM inclinations. A t-test between Kimmeridgian and Tithonian paleolatitudes shows that the latter are more northerly at the $P=0.056$ level, which suggests northward motion of the Pacific Plate during this time, although at a confidence level that falls slightly short of the common $\mathrm{P} \leq 0.05$ criterion.

To quantify the north-south velocity of the Pacific Plate, we computed mean paleolatitudes for samples within each radiolarian biozone as defined by Matsuoka (1995) (Fig. 6; Table 1). Because the late Callovian JR6 biozone contains only four samples that retain ChRM, we combined all 14 samples from biozones JR5 and JR6 (middle Bathonian to latest Callovian) into one paleolatitude estimate. 
Table 2

Summary of paleolatitudes and mean ages derived from our paleomagnetic experiments.

\begin{tabular}{lllllll}
\hline $\begin{array}{l}\text { Age interval } \\
(\mathrm{Ma})\end{array}$ & $\begin{array}{l}\text { Mean age } \\
(\mathrm{Ma})\end{array}$ & $\begin{array}{l}\text { Number of } \\
\text { samples }\end{array}$ & $\begin{array}{l}\text { Raw } \\
\text { paleolatitude }\end{array}$ & $\begin{array}{l}\text { Mean } \\
\text { bedding }\end{array}$ & $\begin{array}{l}\text { Tilt-corrected } \\
\text { paleolatitude }\end{array}$ & $\begin{array}{l}\text { Uncertainty } \\
(1 \sigma)\end{array}$ \\
\hline $137.1-132.9$ & 135.0 & 3 & $12.3^{\circ} \mathrm{S}$ & $73.8^{\circ} / 2.4^{\circ}$ & $12.7^{\circ} \mathrm{S}$ & $1.8^{\circ}$ \\
$146.7-137.2$ & 142.0 & 11 & $10.0^{\circ} \mathrm{S}$ & $226.0^{\circ} / 6.3^{\circ}$ & $7.7^{\circ} \mathrm{S}$ & $1.8^{\circ}$ \\
$152.1-146.7$ & 149.4 & 10 & $5.5^{\circ} \mathrm{S}$ & $232.4^{\circ} / 9.8^{\circ}$ & $2.7^{\circ} \mathrm{S}$ & $1.3^{\circ}$ \\
$157.3-152.1$ & 154.7 & 9 & $17.8^{\circ} \mathrm{S}$ & $212.3^{\circ} / 14.3^{\circ}$ & $10.4^{\circ} \mathrm{S}$ & $3.8^{\circ}$ \\
$167.1-160.9$ & 164.1 & 10 & $11.0^{\circ} \mathrm{S}$ & $212.3^{\circ} / 14.3^{\circ}$ & $4.5^{\circ} \mathrm{S}$ & $1.6^{\circ}$ \\
\hline
\end{tabular}

\subsection{Igneous samples}

In addition to the set of five mean paleolatitudes derived above from sedimentary samples, we recovered one mean paleolatitude from underlying basaltic samples dated to $167.7 \pm 1.4 \mathrm{Ma}$ (Koppers et al., 2003). Out of the 30 igneous samples, 20 were found to carry a directionally stable high temperature $(\mathrm{H})$ magnetization upon thermal demagnetization (Fig. 4E; Table S3). Applying the same criteria for minimum unblocking temperature and maximum MAD as used above for the sedimentary samples, we find that 11 igneous samples representing 5 cooling units carry stable $\mathrm{H}$ magnetization that may be interpreted as ChRM. We then apply the tilt correction derived from the lowermost sedimentary samples to obtain a mean paleolatitude of $4.4^{\circ} \mathrm{S} \pm 2.0^{\circ}$.

This paleolatitude is lower than the $9^{\circ} \mathrm{S}$ value obtained by Wallick and Steiner (1992), who performed alternating field (AF) demagnetization on 51 basaltic samples and applied a similar $14^{\circ}$ tilt correction. The samples in the earlier study were extracted from Site $801 \mathrm{C}$, resulting in a small gap of $\sim 4$ meters between our lowermost and their uppermost samples. In addition, the use of AF demagnetization and lack of any quality filter based on the demagnetization behavior in the earlier work may contribute to the discrepancy between our paleolatitudes. Due to these differences in methodology, we do not combine the datasets and, instead, adopt our value as the best estimate of paleolatitude (Table 2).

Our igneous paleolatitude of $4.4^{\circ} \mathrm{S} \pm 2.0^{\circ}$ is well within uncertainty of the value derived from interbedded and overlying Bathonian-Callovian sediments $\left(4.5^{\circ} \mathrm{S} \pm 1.6^{\circ}\right.$; Table 2$)$, which is consistent with the lack of inclination shallowing in our sedimentary samples. Even so, due to the small angular changes caused by inclination shallowing at such low latitudes, this comparison between igneous and sedimentary paleolatitudes does not rule out the occurrence of inclination shallowing with flattening factors as small as $\sim 0.6$. We note, however, that for the range of low inclinations observed in our $\mathrm{H}$ magnetization components, inclination shallowing results in an inclination decrease by a nearly constant multiplicative factor, which varies by $<7 \%$ across $>90 \%$ of our samples (Eq. (2) in Kent and Tauxe, 2005). As such, although our derived drift rates for the Pacific Plates are a lower bound due to inclination shallowing, the statistical significance at which we can resolve changes in plate velocity remains unchanged. Inclination shallowing therefore does not affect our core conclusions regard anomalous motion of the Pacific Plate in the Late Jurassic.

\subsection{Paleolatitudinal drift of the Pacific Plate}

We use our tilt-corrected igneous and sedimentary data to quantify the paleolatitudinal drift rates of the Pacific plate through time. We first compute the drift of the Pacific plate between the Tithonian and Valanginian (152.1-132.9 Ma; Fig. 6). Assigning the mean age of each time interval to the corresponding paleolatitude, we find a southward drift rate of $0.69^{\circ} \pm 0.16^{\circ} \mathrm{My}^{-1}$ where the $1 \sigma$ error bar is derived from a Monte Carlo simulation with $5 \times 10^{4}$ trials that account for the uncertainty in the paleolatitude within each time interval. Combining our dataset with that of Steiner and Wallick (1992) results in an improved estimate of $0.74^{\circ} \pm 0.09^{\circ} \mathrm{My}^{-1}$. This southward drift rate is also closely consistent with the value of $0.73^{\circ} \mathrm{My}^{-1}$ derived from marine magnetic skewness observations that include correction for anomalous skewness (Larson and Sager, 1992). Combining these additional data, we conclude that the southward drift of the Pacific plate at $0.74^{\circ} \pm 0.09^{\circ} \mathrm{My}^{-1}$ is robustly documented between 132.9 and 152.1 Ma (Larson et al., 1992; Larson and Sager, 1992; Steiner and Wallick, 1992).

Within the Kimmeridgian-Tithonian interval (157.3-146.7 Ma; Table 1), which closely overlaps with the interval of proposed TPW, our tilt-corrected paleolatitudes yield a northward drift rate of $1.45^{\circ} \pm 0.76^{\circ} \mathrm{My}^{-1}$. For times before the Kimmeridgian-Tithonian shift, a linear regression of our igneous and Bathonian to Kimmeridgian sedimentary paleolatitudes yields a southward drift rate of $0.49^{\circ} \pm 0.34^{\circ} \mathrm{My}^{-1}$. Although this best-fit value is close to the Tithonian-Valanginian drift rate derived above, the large uncertainty cannot rule out a constant or even a northward trending paleolatitude. Because several lava flows in our analysis are represented by only one stable paleomagnetic specimen (Table R3), we cannot confirm that the mean directions of successive basalt flows that provide our igneous paleolatitude are fully sampling paleosecular variations (PSV) (Cox and Gordon, 1984). Assuming that the igneous paleolatitude does not adequately sample PSV, we try removing it from our analysis to obtain a pre-Kimmeridgian southward drift rate of $0.61^{\circ} \pm 0.43^{\circ} \mathrm{My}^{-1}$, which is indistinguishable from the rate derived above from both igneous and sedimentary data. The inclusion of the igneous data therefore does not substantially affect our subsequent analysis.

We note that using the older radiolarian biostratigraphy of Matsuoka (1992) results in velocities of $0.67^{\circ} \pm 0.08^{\circ} \mathrm{My}^{-1}$ south, $0.92^{\circ} \pm 0.48^{\circ} \mathrm{My}^{-1}$ north, and $0.89^{\circ} \pm 0.66^{\circ} \mathrm{My}^{-1}$ south in the Tithonian-Valanginian, Kimmeridgian-Tithonian, and BathonianOxfordian intervals, respectively. All three rates are consistent at the $1 \sigma$ level with those derived above using the Matsuoka (1995) geochronology.

\section{Discussion}

\subsection{Origin of Pacific Plate motion}

The Late Jurassic TPW hypothesis predicts that TPW in the 160-145 Ma interval contributed a $1.87^{\circ} \mathrm{My}^{-1}$ component of northward motion to the Pacific Plate (see Introduction). We therefore examine our data for evidence of anomalous northward velocity in the 160-145 Ma interval.

The raw drift velocity found from our tilt-corrected sedimentary inclinations in the $157.3-146.7 \mathrm{Ma}$ interval is $1.45^{\circ} \pm 0.76^{\circ} \mathrm{My}^{-1}$ north (Fig. 6), which is distinguishable from zero at the $1.90 \sigma$ level $(P=0.056)$. Our data therefore suggests that the Pacific Plate moved northward during the candidate TPW interval, although it falls slightly short of the common $P=0.05$ threshold. However, determining the occurrence of a northward change in Pacific Plate velocity requires comparison with background drift rates before and after the Kimmeridgian-Tithonian interval. Performing this analysis, we find that Pacific Plate velocity within this interval is significantly more northerly at the $2.33 \sigma$ and $2.86 \sigma$ 

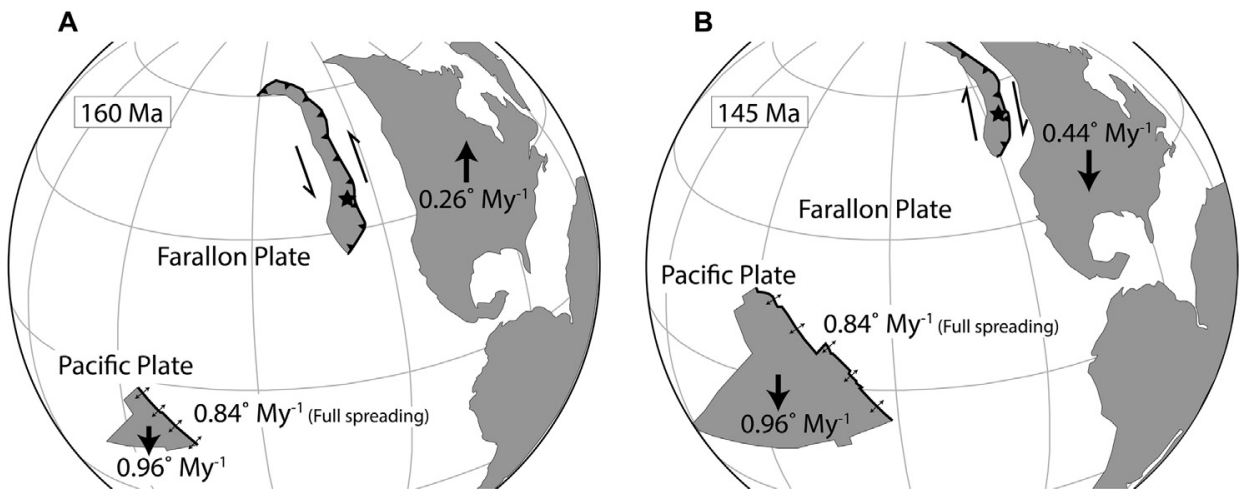

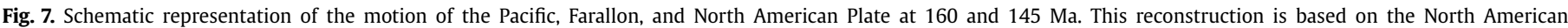

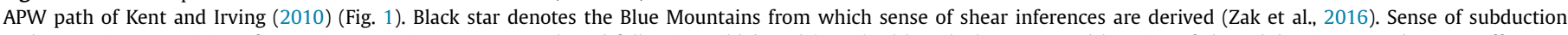

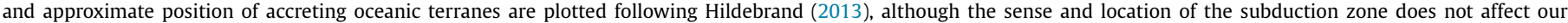
results. The paleolongitude of Pacific Plate is not known quantitatively and plotted approximately according to the reconstruction of Seton et al. (2012).

levels, respectively. Using the alternative chronology of Matsuoka (1992), we find that velocity in the Oxfordian-Tithonian interval is resolvable from earlier and later drift rates at the $3.26 \sigma$ and $2.22 \sigma$ levels, respectively. We therefore robustly conclude that the Pacific Plate underwent anomalous northward motion between approximately Kimmeridgian and Tithonian time regardless of the assumed chronology.

We compare the timing of this northward shift of the Pacific Plate to that of the candidate TPW interval. According to the chronology of Matsuoka (1995), the age range represented by the core segments corresponding to the beginning and end of the shift (32R-21R) represent the 157.3 to $146.7 \mathrm{Ma}$ interval (Fig. 6; Table 1). As such, the paleolatitudinal shift inferred from these core segments is fully consistent with the hypothesized occurrence of TPW in the 160-145 Ma interval. Adopting the alternative chronology of Matsuoka (1992), the time interval sampled by the critical core segments expands to $163.5-146.7 \mathrm{Ma}$, which is still consistent with the TPW hypothesis given that composite poles in the global APW path of continents have chronological uncertainties of several My due to the binning of individual paleomagnetic poles. We therefore conclude that the timing of anomalous northward Pacific Plate motion is fully consistent with that of the candidate Late Jurassic TPW event.

To compare quantitatively the velocity of anomalous northward motion with that predicted by the TPW hypothesis, we must first characterize any component of the Pacific Plate's motion relative to the underlying mantle. Because no dataset can independently quantify the rate of Pacific Plate tectonic drift, we consider two end-member scenarios. First, we assume that the Pacific Plate, which underwent southward tectonic drift of $0.49^{\circ} \pm 0.34^{\circ} \mathrm{My}^{-1}$ and $0.74^{\circ} \pm 0.09^{\circ} \mathrm{My}^{-1}$ before and after the interval of northward motion, continued this motion into the intervening KimmeridgianTithonian interval. Adopting a mean southward tectonic velocity of $0.62^{\circ} \pm 0.35^{\circ} \mathrm{My}^{-1}$ during this time, our inferred net drift rate of $1.45^{\circ} \pm 0.76^{\circ} \mathrm{My}^{-1}$ north implies a velocity component of $2.07^{\circ} \pm 0.84^{\circ} \mathrm{My}^{-1}$ north due to TPW, which is consistent with the expected velocity of $1.87^{\circ} \mathrm{My}^{-1}$ based on continental data (Fig. 1; Kent et al., 2015). We note that this velocity is within the theoretical bounds of TPW (or APW) based on a wide range of mantle viscosities (Tsai and Stevenson, 2007).

Second, we can place a more stringent lower bound on the velocity of TPW-induced northward motion by dropping the assumption of continued southward tectonic motion in the KimmeridgianTithonian interval. Instead, we assume that the tectonic velocity of the Pacific Plate acquired a northerly component during this time. We note that this scenario is unlikely as it requires a northerly change in tectonic velocity and an opposite change of similar magnitude to be timed coincidentally with the proposed TPW episode.
To estimate an upper bound on the change in Pacific Plate tectonic velocity in a $\sim 5 \mathrm{My}$ interval (i.e., one-half of the interval of anomalous northward motion), we sample the latitudinal drift rates of the Pacific Plate between $150 \mathrm{Ma}$ and the present at $5 \mathrm{My}$ intervals. We find that the largest change in velocity attributable to tectonic drift was a northward shift of $0.52^{\circ} \mathrm{My}^{-1}$ that occurred between 137.5 and $132.5 \mathrm{My}$ (Larson et al., 1992). Adopting this value as the largest possible change in north-south tectonic velocity in $\sim 5 \mathrm{My}$, the most northerly possible tectonic velocity of Pacific Plate in the Kimmeridgian-Tithonian may be found by summing $0.74^{\circ} \pm 0.09^{\circ} \mathrm{My}^{-1}$ south and $0.52^{\circ} \mathrm{My}^{-1}$ north, which yields a southward velocity of $0.22^{\circ} \pm 0.09^{\circ} \mathrm{My}^{-1}$. Comparing this tectonic velocity and the net Kimmeridgian-Tithonian northward drift of $1.45^{\circ} \pm 0.76^{\circ} \mathrm{My}^{-1}$ implies that TPW contributed a minimum northward velocity of $1.67^{\circ} \pm 0.77^{\circ} \mathrm{My}^{-1}$, which is again consistent with the prediction of $1.87^{\circ} \mathrm{My}^{-1}$ and resolvable from zero at the $2.18 \sigma$ level.

We therefore conclude that, even in the case of coincidental northward tectonic motion of the Pacific Plate, an additional northward velocity contribution from TPW consistent with the predicted value from continental data is required to explain the inferred net velocity. We emphasize that, although the absolute northward motion of the Pacific Plate during the 157-147 Ma time interval is not statistically significant at $2 \sigma\left(1.45^{\circ} \pm 0.76^{\circ} \mathrm{My}^{-1}\right)$, we do observe a statistically significant northward change in the velocity of the Pacific Plate, which is consistent with the prediction from a TPW scenario.

\subsection{Implications for Farallon-North America motion}

An independent, albeit qualitative, constraint on the Late Jurassic motion of the Pacific Plate comes from petrofabric studies on the western margin of North America. The Pacific and North American Plates during the time period of interest were separated by the Farallon Plate, which contacted the Pacific Plate at a spread center (i.e., the Hawaiian Ridge) and subducted beneath the North American Plate (Fig. 7; Sager et al., 1988). We can therefore compute the sense of shear between the Farallon and North American Plates using our paleolatitudes of the Pacific Plate, an estimate of the spreading rate between the Pacific and Farallon Plates, and published APW paths for North America. The results of this analysis can then be compared to measurements of rock fabric in the Blue Mountains, Oregon, which suggest sinistral, orthogonal, and dextral motion between the two plates at $160.2 \pm 1.1,146.7 \pm 1.2$, and $140.2 \pm 0.7 \mathrm{Ma}$, respectively ( $1 \sigma$; Johnson et al., 2015; Zak et al., 2016).

Due to the north-south strike of the Farallon-North American subduction zone, the sense of shear at this interface depends 
Table 3

Summary of north-south motions for the Pacific, Farallon, and North American plates based on our paleolatitudes and published continental apparent polar wander (APW) paths in the paleomagnetic reference frame (see text).

\begin{tabular}{|c|c|c|c|c|c|c|}
\hline \multirow{2}{*}{$\begin{array}{l}\text { Age } \\
\text { (Ma) }\end{array}$} & \multirow{2}{*}{$\begin{array}{l}\text { Pacific Plate motion } \\
\left({ }^{\circ} / \mathrm{My}\right)\end{array}$} & \multirow{2}{*}{$\begin{array}{l}\text { Farallon Plate motion } \\
\left({ }^{\circ} / \mathrm{My}\right)\end{array}$} & \multicolumn{2}{|c|}{ Kent and Irving (2010) } & \multicolumn{2}{|c|}{ Torsvik et al. (2012) } \\
\hline & & & $\begin{array}{l}\text { N. America } \\
\text { motion } \\
(\% / \mathrm{My})\end{array}$ & Sense of shear & $\begin{array}{l}\text { N. America } \\
\text { motion } \\
\left({ }^{\circ} / \mathrm{My}\right)\end{array}$ & Sense of shear \\
\hline $160.2 \pm 2.1$ & $0.49 \mathrm{~S}$ & $0.11 \mathrm{~N}-0.15 \mathrm{~N}$ & $0.26 \mathrm{~N}-1.57 \mathrm{~N}$ & Sinistral & $0.41 \mathrm{~N}$ & Sinistral \\
\hline $146.7 \pm 2.3$ & $0.74 \mathrm{~S}$ & $0.05 \mathrm{~N}-0.09 \mathrm{~N}$ & $0.44 \mathrm{~S}-1.57 \mathrm{~N}$ & Unconstrained & $0.88 \mathrm{~N}$ & Sinistral \\
\hline $140.2 \pm 1.4$ & $0.74 \mathrm{~S}$ & $0.09 \mathrm{~N}-0.12 \mathrm{~N}$ & $0.44 \mathrm{~S}-0.37 \mathrm{~S}$ & Dextural & $0.07 \mathrm{~S}-0.88 \mathrm{~N}$ & Unconstrained \\
\hline
\end{tabular}

Notes: The three chosen ages reflect times at which the relative motion between the Farallon and North American Plates is constrained by petrographic observations (Zak et al., 2016). The inferred sense of shear at the Farallon-North American Plate interface is sinistral, orthogonal, and dextral at 160.2, 146.7, and $140.2 \mathrm{Ma}$, respectively. Lower and Upper bounds of Farallon Plate motion are computed by assuming a $7.8^{\circ}$ clockwise and $4^{\circ}$ counterclockwise rotation of the Pacific Plate, respectively, which correspond to the $1 \sigma$ range in vertical axis rotation of the Pacific Plate as constrained by the declinations of our $\mathrm{H}$ magnetizations. Latitudinal drift of North America is computed for Sacajawea Peak in Oregon, USA near the localities for which the sense of shear was inferred by Zak et al. (2016).

solely on the north-south component of relative motion between the Farallon and North American Plates (Fig. 7; Table 3). To quantify the motion of the Farallon Plate, we adopt a full spreading rate of $8.4^{\circ} \mathrm{My}^{-1}$ at the Hawaiian Ridge and a Euler pole at $12.8^{\circ} \mathrm{S} 43.6^{\circ} \mathrm{W}$ in a paleomagnetic reference frame (Seton et al., 2012) for the Farallon Plate at 160 Ma (Malinverno et al., 2012; Tominaga and Sager, 2010). Because TPW does not cause change in the relative positions of plates, we advect the Farallon Plate Euler pole with time using only the mean tectonic drift rate of the Pacific Plate, which, as above, is assumed to be $0.62^{\circ} \pm 0.35^{\circ} \mathrm{My}^{-1}$ south around an equatorial Euler pole with longitude $22^{\circ} \mathrm{W}$ (see Introduction). We compute the north-south motion of the Farallon Plate assuming vertical axis rotations in the range $1.9^{\circ} \pm 5.9^{\circ}$ for the Pacific Plate based on our recovered $\mathrm{H}$ component declinations (see Results).

We use the above rotation parameters to compute the northsouth velocity of the Farallon plate at a location in present-day Oregon near the Blue Mountains with coordinates $40.7^{\circ} \mathrm{N} 50.9^{\circ} \mathrm{W}$ at $160 \mathrm{Ma}$ and $43.5^{\circ} \mathrm{N} 55.3^{\circ} \mathrm{W}$ at $140 \mathrm{Ma}$ (Seton et al., 2012). The reconstruction used to find the location of the Farallon-North America contact location has a negligible effect on the derived sense of shear. We find that paleolatitudinal drift velocities for the Pacific Plate predicts northward motion of the Farallon Plate at the North American margin with rates $0.13^{\circ} \mathrm{My}^{-1}$ at $160.2 \mathrm{Ma}$, $0.07^{\circ} \mathrm{My}^{-1}$ at $146.7 \mathrm{Ma}$, and $0.10^{\circ} \mathrm{My}^{-1}$ at $140.2 \mathrm{Ma}$. (Table 3).

Adopting the APW path for North America from Kent and Irving (2010), our predicted sense of shear at the Pacific-Farallon margin is consistent with measurements at 160.2 and $140.2 \mathrm{Ma}$, while the sense of shear cannot be determined at 146.7 Ma due to uncertainties in the end timing of rapid northward North America motion (Table 3). Using an alternative North America APW path from Torsvik et al. (2012), we find that the sense of shear at 160 $\mathrm{Ma}$ is consistent with observations while that at $146 \mathrm{Ma}$ is inconsistent. For $140 \mathrm{Ma}$, the sense of shear is unconstrained, again due to chronological uncertainties in the APW path. We therefore conclude that, adopting the igneous sample-derived APW path of Kent and Irving (2010), our paleomagnetically determined Pacific Plate velocities are consistent with the inferred sense of shear on the Farallon-North America margin, although improved chronologies for the North American APW path would further test this correspondence. Meanwhile, the disagreement in the inferred and measured sense of shear at 146.7 Ma using the Torsvik et al. (2012) North American APW path may be due to the choice of binning intervals compared to the Kent and Irving (2010) compilation.

In summary, our paleomagnetically-inferred velocities of the Pacific Plate between 167 and 133 Ma strongly suggest an anomalous northward velocity between Kimmeridgian and Tithonian time (approximately 157.3-146.7 Ma). The existence of this northward component of motion is independent of the choice of biostratigraphic chronologies and assumptions for the tectonic drift veloc- ity of the Pacific Plate. The amplitude and timing of this northward motion is consistent with those predicted by an episode of TPW between approximately 160 and $145 \mathrm{Ma}$ (Kent et al., 2015). Finally, the sense of motion at the Farallon-North American Plate margin inferred from petrofabric measurements in the Blue Mountains of Oregon is consistent with the drift rates of the Pacific Plate presented here. We therefore conclude that our ODP 801B core measurements provide strong evidence for the participation of the Pacific Plate and its adjacent oceanic plates in the rapid rotation of $28.6^{\circ}$ amplitude recorded in continental plates during the 160-145 Ma interval. Although a greater number of paleomagnetic specimens would lower our uncertainties for Pacific paleolatitudes, this study has exhausted the orientable samples available from critical intervals of Site 801B. Future ocean floor drilling of the oldest Pacific crust with higher recovery fraction is likely required to improve significantly the paleomagnetic record of motion in the Late Jurassic.

\subsection{Implications for the true polar wander hypothesis}

The coherent motion of both the continents and the Pacific Plate, which was coupled to the other major plates of the Pacific Basin via mid-ocean ridges, implies that a significant majority of the Earth's lithosphere participated in a large-amplitude rotation in the 160-145 Ma interval. As discussed in the Introduction, relative rotation of the entire lithosphere with respect to the deep mantle likely occurs at slow rates of $<0.2^{\circ} \mathrm{My}^{-1}$. Therefore, the simultaneous rapid $\left(\sim 1.9^{\circ} \mathrm{My}^{-1}\right)$ motion of a large fraction of the lithosphere in the Late Jurassic was very likely coupled to the deep mantle and not a consequence of tectonic motion of the lithosphere alone. As such, we conclude that our data provides strong support for the occurrence of large amplitude TPW in the Late Jurassic.

The occurrence of TPW in the 160-145 Ma interval requires that a significant redistribution of mass took place in the Earth's mantle or crust during this time. Possible mechanisms that can advect sufficient mass to drive a TPW rotation of nearly $30^{\circ}$ amplitude include mantle plumes and the subductions of major oceanic slabs (Greff-Lefftz, 2004; Greff-Lefftz and Besse, 2014). Although no large igneous province (LIP) was active during the 160-145 Ma interval, upwelling of material beneath the established KarooFerrar LIP ( $\sim 184 \mathrm{Ma}$; Jourdan et al., 2005) or the rise of a nascent plume that would form the Paraná-Etendeka LIP ( $135 \mathrm{Ma}$; Gibson et al., 2006) may have perturbed the Earth's inertia tensor.

At the same time, the subduction of oceanic slabs was occurring on the western margin of North America and the MongolOkhtosk Ocean between Siberia and China (Cogné et al., 2005; Van der Voo et al., 2015). Larger angular separations from the TPW axis, inferred to be immediately south of West Africa for the Late Jurassic event (Kent et al., 2015), results in greater rotation for 
a given mass anomaly. The subduction zones enumerated above, located $65^{\circ}$ and $70^{\circ}$ from the TPW axis, respectively, are more optimally positioned than the LIPs to drive TPW rotation. If subducting slabs are invoked as possible driving mechanisms for TPW, the sudden onset and relatively short $(\sim 15 \mathrm{My})$ duration of the Late Jurassic event must be reconciled with the continuous nature of subduction. One possible scenario involves the build-up and rapid descent of subducted material at the upper-lower mantle interface in a slab avalanche event (Pysklywec and Ishii, 2005). At the same time, the assembly of the ribbon continent Rubia in the Eastern Pacific (Fig. 7) may have occurred at approximately $160 \mathrm{Ma}$ (Hildebrand, 2013; Sigloch and Mihalynuk, 2013), which led to the cessation of subduction and subsequent break-off of a slab. The sinking of such a truncated slab through the upper mantle would have perturbed the Earth's inertia tensor.

All of the potential driving mechanisms of Late Jurassic TPW cited here are qualitatively plausible but lack quantitative geodynamical assessment. Future models that consider the magnitude of perturbation on the inertia tensor and the resulting trajectory of TPW are necessary to validate or preclude these scenarios. These models may consider mantle tomographic constraints on the location and size of subducted slabs from the relevant time interval (Fritzell et al., 2016; Sigloch and Mihalynuk, 2013; D.G. van der Meer et al., 2010) as well as a range of possible assumptions for lithospheric strength and mantle rheology (Creveling et al., 2012).

Finally, the occurrence of large-amplitude TPW in the Late Jurassic holds implications for the interpretation of paleoenvironmental and sea-level records. Because TPW results in sea-level rise and fall in alternating quadrants of the Earth (e.g., Mound and Mitrovica, 1998), transgressions and regressions observed in the local sea-level record during an interval of TPW may be strongly biased based on their location relative to the axis of TPW rotation. Nearly continuous records of sea-level change are available in select locations during the Late Jurassic. Among these, data from the Russian Platform and the North Sea appear to show sea-level rise (Sahagian et al., 1996; Vail et al., 1984), while records from the Arabian Platform qualitatively show sea-level fall (Haq and Al-Qahtani, 2005). The location of the Arabian Platform in an adjacent quadrant compared to the other localities implies that the opposite sign of sea-level change is fully consistent with a TPW origin while inconsistent with eustatic sea-level change (Muttoni and Kent, 2016). Sea-level records during time intervals of possible TPW should therefore be corrected for its effects before being used to infer global, eustatic change.

\section{Conclusion}

By densely sampling remaining materials from the ODP Site 801B recovered from the oldest Pacific crust, we obtained six new mean paleolatitudes for the Pacific Plate between Bathonian and Valanginian time (167-133 Ma). Our igneous samples imply a paleolatitude of $4.4^{\circ} \mathrm{S} \pm 2.0^{\circ}$ at $167 \pm 1.4$ Ma while our paleolatitudes derived from the overlying tilt-corrected sediments show southward drift of the Pacific Plate at $0.49^{\circ} \pm 0.34^{\circ} \mathrm{My}^{-1}$ before the Kimmeridgian and at $0.74^{\circ} \pm 0.09^{\circ} \mathrm{My}^{-1}$ after the Tithonian. The latter velocity includes and is consistent with previous paleomagnetic results from Steiner and Wallick (1992).

Critically, tilt-corrected sedimentary samples between Kimmeridgian and Tithonian age (157.3-146.7 Ma) show northward motion $1.45^{\circ} \pm 0.76^{\circ} \mathrm{My}^{-1}$ (Fig. 6; Table 2). This anomalous northward motion remains robust independent of the assumed biostratigraphic age model. Furthermore, its timing and velocity agree with predictions from the Late Jurassic TPW hypothesis (Kent et al., 2015), even when assuming a range of possible velocities for the tectonic drift of the Pacific Plate over the deep mantle. Finally, the inferred sense of shear between the Farallon and North Amer- ican Plates between 160.2 and 140.1 Ma are consistent with our paleolatitude results.

Our results therefore suggest that large amplitude TPW occurred as recently as the Late Jurassic. Such an event may be due to mass perturbations in the mantle due to the sinking of subducted slabs in the Mongol-Okhotsk ocean or the Cordillera of western North America. Alternatively, the rise of deep mantle material as part of the established South Atlantic plume associated with the Karoo-Ferrar LIP or the forthcoming plume that caused the later Paraná-Etendeka LIP may have contributed to shifting the Earth's inertia tensor. Further theoretical work investigating the plausibility of these driving mechanisms can yield further insights on the evolution of mass anomalies in the mantle, while further paleomagnetic experiments on both continental and oceanic crust material during the Late Jurassic to Early Cretaceous will refine the estimates for the timing and rate of TPW motion.

\section{Acknowledgements}

We thank Nichole Anest, Gilles Guerín, and Phil Rumsford for their generous help with acquiring and documenting the core samples. We also thank Jeff Gee for help with the paleomagnetic measurement software and Alberto Malinverno for helpful discussions. Finally, we appreciate a thorough review by an anonymous referee. RRF is supported by the Lamont-Doherty Post-Doctoral Fellowship. Further support for this work came from a Lamont-Doherty Earth Observatory Climate Center Grant.

\section{Appendix A. Supplementary material}

Supplementary material related to this article can be found online at https://doi.org/10.1016/j.epsl.2018.02.034.

\section{References}

Bartolini, A., Larson, R.L., 2001. Pacific microplate and the Pangea supercontinent in the Early to Middle Jurassic. Geology 29, 735-738.

Cogné, J.-P., Kravchinsky, V.A., Halim, N., Hankard, F., 2005. Late Jurassic-Early Cretaceous closure of the Mongol-Okhotsk Ocean demonstrated by new Mesozoic palaeomagnetic results from the Trans-Baikal area (SE Siberia). Geophys. J. Int. $163,813-832$

Cottrell, R.D., Tarduno, J.A., 2000. Late Cretaceous true polar wander: not so fast. Science 288, 2283a.

Courtillot, V., Davaille, A., Besse, J., Stock, J., 2003. Three distinct types of hotspots in the Earth's mantle. Earth Planet. Sci. Lett. 205, 295-308.

Cox, A., Gordon, R.G., 1984. Paleolatitudes determined from paleomagnetic data from vertical cores. Rev. Geophys. Space Phys. 22, 47-72.

Creveling, J.R., Mitrovica, J.X., Chan, N.-H., Latychev, K., Matsuyama, I., 2012. Mechanisms for oscillatory true polar wander. Nature 491, 244-248.

Dunlop, D.J., Ozdemir, O., 1997. Rock Magnetism: Fundamentals and Frontiers. Cambridge Studies in Magnetism. Cambridge University Press, New York.

Erba, E., Covington, J.M., 1992. Calcareous nannofossil biostratigraphy of Mesozoic sediments recovered from the western Pacific, Leg 129. In: Proceedings of the Ocean Drilling Program, Scientific Results, vol. 129, pp. 179-187.

Fritzell, E.H., Bull, A.L., Shephard, G., 2016. Closure of the Mongol-Okhotsk Ocean: insights from seismic tomography and numerical modelling. Earth Planet. Sci. Lett. 445, 1-12.

Gibson, S.A., Thompson, R.N., Day, J.A., 2006. Timescales and mechanisms of plumelithosphere interactions: $40 \mathrm{Ar} / 39 \mathrm{Ar}$ geochronology and geochemistry of alkaline igneous rocks from the Paraná-Etendeka large igneous province. Earth Planet. Sci. Lett. 251, 1-17.

Gold, T., 1955. Instability of the Earth's axis of rotation. Nature 175, 526-529.

Gordon, R.G., 1995. Plate motions, crustal and lithospheric mobility, and paleomagnetism: prospective viewpoint. J. Geophys. Res. 100, 24,367-24,392.

Gordon, R.G., 1983. Late Cretaceous apparent polar wander of the Pacific Plate: evidence for a rapid shift of the Pacific hotspots with respect to the spin axis. Geophys. Res. Lett. 10, 709-712.

Gordon, R.G., Jurdy, D.M., 1986. Cenozoic global plate motions. J. Geophys. Res. 91, $12,389-12,406$.

Greff-Lefftz, M., 2004. Upwelling plumes, superswells and true polar wander. Geophys. J. Int. 159, 1125-1137.

Greff-Lefftz, M., Besse, J., 2014. Sensitivity experiments on True Polar Wander Geochem. Geophys. Geosyst. 15, 4599-4616. 
Haq, B.U., Al-Qahtani, A.M., 2005. Phanerozoic cycles of sea-level change on the Arabian Platform. GeoArabia 10, 127-159.

Hildebrand, R.S., 2013. Mesozoic Assembly of the North American Cordillera. Geological Society Special Publications.

Johnson, K., Schwartz, J.J., Zak, J., Verner, K., Barnes, C.G., Walton, C., Wooden, J.L., Wright, J.E., Kistler, R.W., 2015. Composite Sunrise Butte pluton: insights into Jurassic-Cretaceous collisional tectonics and magmatism in the Blue Mountains Province, northeastern Oregon. In: Anderson, T.H., Didenko, A.N., Johnson, C.L., Khanchuk, A.I., MacDonald, J.H. (Eds.), Late Jurassic Margin of Laurasia-A Record of Faulting Accommodating Plate Rotation, pp. 377-398.

Jourdan, F., Féraud, G., Bertrand, H., Kampunzu, A.B., Tshoso, G., Watkeys, M.K., Le Gall, B., 2005. Karoo large igneous province: brevity, origin, and relation to mass extinction questioned by new 40Ar/39Ar age data. Geology 33, 745-748.

Jurdy, D.M., Van der Voo, R., 1974. A method for the separation of true polar wander and continental drift, including results for the last 55 m.y. J. Geophys. Res. 79, 2945-2952.

Kent, D.V., Tauxe, L., 2005. Corrected late Triassic latitudes for continents adjacent to the North Atlantic. Science 307, 240-244.

Kent, D.V., Irving, E., 2010. Influence of inclination error in sedimentary rocks on the Triassic and Jurassic apparent pole wander path for North America and implications for Cordilleran tectonics. J. Geophys. Res. 115, B10103.

Kent, D.V., Kjarsgaard, B.A., Gee, J.S., Muttoni, G., Heaman, L.M., 2015. Tracking the Late Jurassic apparent (or true) polar shift in U-Pb-dated kimberlites from cratonic North America (Superior Province of Canada). Geochem. Geophys. Geosyst. 16, 983-994.

Kirschvink, J.L., 1980. The least-squares line and plane and the analysis of paleomagnetic data: examples from Siberia and Morocco. Geophys. J. R. Astron. Soc. 62, 699-718.

Koppers, A.A.P., Staudigel, H., Duncan, R.A., 2003. High-resolution 40Ar/39Ar dating of the oldest oceanic basement basalts in the western Pacific basin. Geochem. Geophys. Geosyst. 4, 8914.

Lancelot, Y.P., Larson, R., Fisher, A., Abrams, L., Behl, R., Busch, W.H., Cameron, G., Castillo, P.R., Covington, J.M., Dürr, G., Erba, E., Floyd, P.A., France-Lanord, C., Hauser, E.H., Karl, S.M., Karpoff, A.-M., Matsuoka, A., Molinie, A., Ogg, J.G., Salimullah, A.R.M., Steiner, M., Wallick, B.P., Wightman, W., Fisher, A., 1990. In: Proceedings of the Ocean Drilling Program, Initial Reports, vol. 129. Ocean Drilling Program, College Station, TX.

Larson, R.L., Sager, W.W., 1992. Skewness of magnetic anomalies M0-M29 in the Northwestern Pacific. In: Proceedings of the Ocean Drilling Program, Scientific Results, vol. 129, pp. 471-481.

Larson, R.L., Steiner, M.B., Erba, E., Lancelot, Y., 1992. Paleolatitudes and tectonic reconstructions of the oldest portion of the Pacific plate: a comparative study In: Proceedings of the Ocean Drilling Program, Scientific Results, vol. 129, pp. 615-631.

Malinverno, A., Hildebrandt, J., Tominaga, M., Channell, J.E.T., 2012. M-sequence geomagnetic polarity time scale (MHTC12) that steadies global spreading rates and incorporates astrochronology constraints. J. Geophys. Res. 117, B06104.

Matsuoka, A., 1995. Jurassic and Lower Cretaceous radiolarian zonation in Japan and in the western Pacific. Isl. Arc 4, 14-153.

Matsuoka, A., 1992. Jurassic and early Cretaceous radiolarians from Leg 129, Sites 800 and 801, western Pacific Ocean. In: Proceedings of the Ocean Drilling Program, Scientific Results, vol. 129, pp. 203-220.

McElhinny, M.W., 1973. Mantle plumes, palaeomagnetism and polar wandering. Nature 241, 523-524.

McFadden, P.L., McElhinny, M.W., 1990. Classification of the reversal test in paleomagnetism. Geophys. J. Int. 103, 725-729.

McKenzie, D.P., 1972. Plate tectonics. In: Nature of the Solid Earth. McGraw-Hill, New York, pp. 323-360.

Molinie, A.J., Ogg, J.G., 1992. 36. Data report: formation microscanner imagery of lower Cretaceous and Jurassic sediments from the western Pacific (Site 801). In: Larson, R.L., Lancelot, Y. (Eds.), Proceedings of the Ocean Drilling Program, Scientific Results, vol. 129, pp. 671-691.

Mound, J.E., Mitrovica, J.X., 1998. True polar wander as a mechanism for secondorder sea-level variation. Science 279, 534-537.

Müller, R.D., Royer, J.-Y., Lawver, L.A., 1993. Revised plate motions relative to the hotspots from combined Atlantic and Indian Ocean hotspot tracks. Geology 21, 275-278.

Muttoni, G., Dallanave, E., Channell, J.E.T., 2013. The drift history of Adria and Africa from $280 \mathrm{Ma}$ to Present, Jurassic true polar wander, and zonal climate control on Tethyan sedimentary facies. Palaeogeogr. Palaeoclimatol. Palaeoecol. 386, 415-435.
Muttoni, G., Kent, D.V., 2016. A novel plate tectonic scenario for the genesis and sealing of some major Mesozoic oil fields. GSA Today 26, 4-10.

O'Connell, R.J., Hager, B.H., 1990. Toroidal-poloidal partitioning of lithospheric plate motions. In: Glacial Isostasy, Sea-Level and Mantle Rheology. Kluwer Academic Publishers, pp. 535-551.

Ogg, J.G., 2012. Geomagnetic polarity time scale. In: Gradstein, F.M., Ogg, J.G., Schmitz, M., Ogg, G. (Eds.), The Geologic Time Scale 2012. Elsevier B.V., pp. 65-113.

Pysklywec, R.N., Ishii, M., 2005. Time dependent subduction dynamics driven by the instability of stagnant slabs in the transition zone. Phys. Earth Planet. Inter. 149, $115-132$.

Sager, W.W., Handschumacher, D.W., Hilde, T.W.C., Bracey, D.R., 1988. Tectonic evolution of the northern Pacific plate and Pacific-Farallon-Izanagi triple junction in the Late Jurassic and Early Cretaceous (M21-M10). Tectonophysics 155, 345-364.

Sager, W.W., Koppers, A.A.P., 2000. Late Cretaceous polar wander of the Pacific plate: evidence of a rapid true polar wander event. Science 287, 455-459. https://doi. org/10.1126/science.287.5452.455.

Sahagian, D., Pinous, O., Olferiev, A., Zakharov, V., 1996. Eustatic curve for the Middle Jurassic-Cretaceous based on Russian Platform and Siberian stratigraphy: zonal resolution. AAPG Bull. 80, 1433-1458.

Seton, M., Müller, R.D., Zahirovic, S., Gaina, C., Torsvik, T.H., Shephard, G., Talsma, A., Gurnis, M., Turner, M., Maus, S., Chandler, M., 2012. Global continental and ocean basin reconstructions since 200 Ma. Earth-Sci. Rev. 113, 212-270.

Sigloch, K., Mihalynuk, M.G., 2013. Intra-oceanic subduction shaped the assembly of Cordilleran North America. Nature 496, 50-57.

Solomon, S.C., Sleep, N.H., 1974. Some simple physical models for absolute plate motions. J. Geophys. Res. 79, 2557-2567.

Steinberger, B., O'Connell, R.J., 2002. The convective mantle flow signal in rates of true polar wander. In: Ice Sheets, Sea Level, and the Dynamic Earth, pp. 233-256.

Steiner, M.B., Wallick, B.P., 1992. Jurassic to Paleocene paleolatitudes of the Pacific Plate derived from the paleomagnetism of the sedimentary sequences at sites 800, 801, and 802. In: Proceedings of the Ocean Drilling Program, Scientific Results, vol. 129, pp. 431-446.

Tauxe, L., Gee, J.S., Steiner, M.B., Staudigel, H., 2013. Paleointensity results from the Jurassic: new constraints from submarine basaltic glasses of ODP Site 801C. Geochem. Geophys. Geosyst. 14, 4718-4733.

Tominaga, M., Sager, W.W., 2010. Revised Pacific M-anomaly geomagnetic polarity timescale. Geophys. J. Int. 182, 203-232.

Torsvik, T.H., Müller, R.D., Van der Voo, R., Steinberger, B., Gaina, C., 2008. Global plate motion frames: toward a unified model. Rev. Geophys. 46, RG3004.

Torsvik, T.H., Van der Voo, R., Preeden, U., Mac Niocaill, C., Steinberger, B. Doubrovine, P.V., van Hinsbergen, D.J.J., Domeier, M., Gaina, C., Tohver, E., Meert J.G., McCausland, P.J.A., Cocks, L.R.M., 2012. Phanerozoic polar wander, palaeogeography and dynamics. Earth-Sci. Rev. 114, 325-368.

Tsai, V.C., Stevenson, D.J., 2007. Theoretical constraints on true polar wander. J. Geophys. Res. 112, B05415. https://doi.org/10.1029/2005JB003923.

Vail, P.R., Hardenbol, J., Todd, R.G., 1984. Jurassic unconformities, chronostratigraphy, and sea-level changes from seismic stratigraphy and biostratigraphy. In Schlee, J.S. (Ed.), Interregional Unconformities and Hydrocarbon Acculumation. In: American Association of Petroleum Geologists Memoirs, pp. 129-144.

van der Meer, D.G., Spakman, W., van Hinsbergen, D.J.., Amaru, M.L., Torsvik, T.H., 2010. Towards absolute plate motions constrained by lower-mantle slab remnants. Nat. Geosci. 3, 36-40.

Van der Voo, R., van Hinsbergen, D.J., Domeier, M., Spakman, W., Torsvik, T.H. 2015. Latest Jurassic-earliest Cretaceous closure of the Mongol-Okhotsk Ocean: a paleomagnetic and seismological-tomographic analysis. In: Anderson, T.H., Didenko, A.N., Johnson, C.L., Khanchuk, A.I., MacDonal, J.H. (Eds.), Late Jurassic Margin of Laurasia-A Record of Faulting Accommodating Plate Rotation.

Wallick, B.P., Steiner, M.B., 1992. Paleomagnetic and rock magnetic properties of Jurassic Quiet Zone basalts, Hole 801C. In: Proceedings of the Ocean Drilling Program, Scientific Results, vol. 129, pp. 455-470.

Wu, P., Peltier, W.R., 1984. Pleistocene deglaciation and the Earth's rotation: a new analysis. Geophys. J. R. Astron. Soc. 76, 753-791.

Zak, J., Verner, K., Tomek, F., Johnson, K., Schwartz, J.J., 2016. Magnetic fabrics of arc plutons reveal a significant Late Jurassic to Early Cretaceous change in the relative plate motions of the Pacific Ocean basin and North America. Geosphere 12. https://doi.org/10.1130/GES01357.1.

Zhong, S.J., 2001. Role of ocean-continent contrast and continental keels on plate motion, net rotation of lithosphere, and the geoid. J. Geophys. Res. 106 703-712. 